Global Sustainability

cambridge.org/sus

\section{Research Article}

Cite this article: Wallacher J, Einsiedel S, Gösele A (2019). Sustainable development: in space as on Earth? Global Sustainability 2, e15, 1-6. https://doi.org/10.1017/sus.2019.12

Received: 26 June 2018

Revised: 12 July 2019

Accepted: 15 July 2019

\section{Keywords:}

communication and education; policies; politics and governance; social value; human behaviour

Author for correspondence:

Stefan Einsiedel,

E-mail: stefan.einsiedel@hfph.de

\title{
Sustainable development: in space as on Earth?
}

Johannes Wallacher $^{1}$, Stefan Einsiedel ${ }^{2}$ (I) and Andreas Gösele ${ }^{2}$

${ }^{1}$ Chair Holder, Chair for Social Sciences and Economic Ethics, Munich School of Philosophy, Munich, Germany and

${ }^{2}$ Zentrum für Globale Fragen/Global Studies Centre at the Munich School of Philosophy, Munich, Germany

\section{Non-technical abstract}

Although the concept of sustainable development is widely used as a guiding principle, there is much less consensus on its normative foundation and ethical implications. Since the 1880s, when social tensions threatened to tear apart European societies during the Industrial Revolution, Catholic social teaching (CST) has served as a sound basis for dialogue for many political leaders regardless of national or religious affiliation. This article examines how Pope Francis' present-day CST might foster a cross-cultural debate on the ethics of economic growth, social and ecological justice and civil participation on Planet Earth as well as in outer space.

\section{Technical abstract}

In many parts of the world, Catholic social teaching (CST) shapes the discussion of political and ethical guidelines and provides a promising ethical basis for the normative concept of sustainable development. It is engaging in dialogue and serving as a basis for dialogue, as evidenced not least by Pope Francis' social and ecological teaching. In this article, we illustrate that, from a CST perspective, the concept of sustainable development is based on three powerful ideas, which should be acceptable to most people regardless of their individual cultural or religious backgrounds: (1) the idea of the common good; (2) the idea of human rights; and (3) the idea of equal justice. Building on the central idea of the common good - universal and integral - the article shows how this idea connects to and allows us to establish the normative relevance of human rights as a focal point of many (modern) ethical traditions. It also gives content to the basic requirements of justice. These three perspectives together lead to the demands of sustainable development and help to elucidate the nature and role of its various dimensions. The article concludes with implications for the questions of economic growth and the human responsibilities and opportunities transcending Planet Earth.

\section{Social media summary}

Pope Francis' social and ecological teachings are used to discuss sustainability on Earth and in 'space ethics'.

\section{Sustainable development: a guiding principle supported by sound normative foundations}

"Sustainability" is meant to be a life-saving concept - and the discussion around it is probably as competitive and multifaceted as life itself. Despite the increased awareness that most natural resources are limited, that many species are critically endangered and that the biosphere needs much more comprehensive protection, there is still no national, let alone international consensus how this 'vague' concept (Robinson, 2004) should precisely look. This is why the main focus of many debates on sustainability is currently on how to steer always and necessarily ongoing changes towards truly sustainable development - a process - for now and on a practical level, being well described by the Sustainable Development Goals (SDGs) of the 2030 Agenda, a collection of 17 mid-term goals set by the United Nations in 2015 (United Nations General Assembly, 2015). Naturally, a set of 17 goals, defined by 169 targets, affecting 7.6 billion people living on Earth and many more to come, implies countless conflicts of objectives as well as of interests, and even more political and academic discussions of how to best resolve these conflicts. One of the most divisive discussions is currently centred on Goal \#8 to 'promote sustained, inclusive and sustainable economic growth, full and productive employment and decent work for all': a growing number of people (some of them organized in various post-growth movements) argue that economic growth is rather part of the problem than part of a potential solution, while there is a growing consensus that gross domestic product (GDP), which is used to measure 6 of the associated 12 targets, is no adequate indicator for 
measuring the scope and quality of economic growth or human wealth (German Bishops' Conference Research Group on International Church Affairs, 2018; Stiglitz et al., 2009). Furthermore, GDP figures are certainly no adequate motivator for steering individual people or entire nations towards more sustainable development. This discussion is but one instance of one of the main criticisms of the concept of sustainable development: that it is an oxymoron, bringing together two aims that might not be achieved together - ecological sustainability and development the latter meant to include the idea of growth (Redclift, 2005; Robinson, 2004).

The question of sustainability in space is closely connected to this debate on just and sustainable growth on Earth: the idea of space mining is frequently presented as a plausible answer to the challenge of dwindling resources and as a powerful generator of future jobs and economic growth. But the costs of most space activities (on the monetary as well as on the emissions side) will be borne to a large extent by taxpayers, entrepreneurs and our environment, whereas it is not yet clear how the potential benefits will be distributed. While this latent distributional conflict is present for most new technologies, other facets of this debate over the use of outer space are indeed quite new: the debate on sustainability in space has the potential to become one of the first discourses in human history in which the basic rules and ethical principles for accessing an almost unchartered territory (in technical and geographical regards) are agreed on before the main journey starts - and as there are no traditional (terrestrial) property rights that have to be taken into account, there is indeed the chance for a much more transparent and generous debate than could ever be the case for discussions on terrestrial land use and ownership. In fact, John Rawls' famous proposal that a perfectly just society could be best defined by people who discuss it behind a 'veil of ignorance' (Rawls 1971) about their future position in this society could much more easily become reality in debates about justice in space than about justice on Earth.

Since the 1880s, when social tensions threatened to tear European societies apart during the Industrial Revolution, Catholic social teaching (CST) has pondered the question of what helps and motivates people to contribute to a more just and truly 'human' development (Welty 1951). Right from the beginning, the scholars of CST tried to base their proposed principles and insights on a normative basis that should be acceptable and accessible not only to Catholic politicians, but to all Christians, as well as a great variety of conservative, liberal, socialist or agnostic leaders all over - at least - the industrialized world growing out of Christianity. It is important to note that these basic principles of CST, which will be discussed further in the following sections, have not changed over the past 150 years, but that their scope of application has constantly broadened: they were meant to apply mainly to nation states by Pope Leo XIII in Rerum Novarum in 1891, but became truly global in Pope John XXIII's Mater et Magistra and Pacem in Terris in the early 1960s. Pope Paul VI added a special focus to the woes of the developing nations in Populorum Progressio (1967), and Pope Francis widened it to a holistic and 'truly ecological culture' (Scheid, 2016) in his 2015 encyclical Laudato Si'. This article intends to lay out these enduring foundations, as they still serve as a sound basis for international and intercultural dialogue on the 'terms and conditions' of human growth and cooperation and should also be applicable to human activities transcending Planet Earth.

It is useful to start this discussion with a simple but important observation: the often-quoted concept of sustainable development is best described as a guiding principle - which means it is neither just a term with a distinct definition nor a roadmap or a final destination. It is more an auxiliary ideal (Kant's 'regulative idea') within the constant decision-making processes of individuals, companies, states and international organizations. And this entire process of assessing the various options, weighting the implications and discussing potential compromises is helped substantially if the participants are aware of their own and their partners' normative bases. To an interested layperson, the concept of sustainable development could therefore be described as a distant guiding light that gives orientation to travellers in various places, while their ethical basis could be seen as the solid ground that allows the decision-makers to discern this guiding star and their individual surroundings more clearly, to step firmly forwards and to defend and explain their decisions and motivations to their voters and shareholders. One might also describe the ethical basis as the soil that nurtures the growing discussion of how to create a more just and sustainable future - but either way, the concept of sustainable development and its normative bases are best served and used when they are understood as two separate entities and dimensions.

In order to understand the importance of a normative basis for the concept of sustainable development, it is not necessary to explicate the strong current and historic influence of religions and faithbased organizations on economic, social and ecological decisions and how their moral stances and emotional backgrounds might serve as a source of motivation for individuals, social movements and societies as a whole (see Habermas, 2010; Reder \& Müller, 2012). Nor will this article detail how the current interreligious discursive convergence on ecology is increasingly shaping a shared, pluralistic narrative grounded in social justice, care for creation and intergenerational solidarity' (Tatay \& Devitt, 2017; see also Hollenbach, 2012). Its intention is instead to use CST as an example to show how an ethical doctrine, based on religious beliefs, but not limited to them, can have the potential to integrate insights from various traditions of thought, different fields of science and other forms of cultural knowledge to form a plausible normative base that enables public debate and makes the plea for sustainable development more convincing, precise and appealing.

\section{The idea of the common good and the common destination of goods}

To reflect the ethical foundation that informs the concept of sustainable development, we are articulating three different powerful ideas that support and complement each other: the common good, universal human rights and the principles of general justice. Modern scholars (e.g., Scheid, 2016) point out that the latter two - human rights and human justice - are closely linked to the idea of human dignity, whereas the first idea - the common good - 'provides a vision of wholeness and ... interconnectedness' (Scheid, 2016, p. 19) of life on Earth that reminds us that 'the common good and human dignity strengthen, rather than oppose each other' (p. 18). To understand the historic interdependence between these three ideas, it is worth starting by taking a look at the structure and storyline of Rerum Novarum, the Vatican's founding document of modern CST, published by Pope Leo XIII in 1891: confronted with working men's social and economic woes, the encyclical ponders the 'rights and duties of capital and labor' (the subtitle of the document). Even now, 128 years after its publication, it is still inspiring to see how Pope Leo intertwines scientific analysis and personal empathy, especially in the first 
chapters, and argues that just remedies to man-made problems will only become evident if man's nature is 'considered a little more deeply' (Pope Leo XIII, 1891, Rerum Novarum 7). This holistic view of man's nature, which combines scientific, religious and cultural sources of knowledge as well as personal empathy, leads to the idea of a common good. In a first step, it acknowledges that man who has the skills and capabilities to plan his future and to care for himself and his family, and who has the natural right to create and possess the goods that are necessary for that purpose. In a second step, it also becomes obvious that such a man, who does not create himself, is at the same time part of a larger family and society that needs, creates, uses or guards a joint 'commonwealth' or common good that is just as essential to his well-being as his private goods. This common good can only be sustained and enjoyed by all parts of the group if both the individual and the common rights and duties and various aspects of justice are well understood and wisely balanced against each other:

\footnotetext{
As regards the State, the interests of all, whether high or low, are equal. The members of the working classes are citizens by nature and by the same right as the rich; they are real parts, living the life which makes up, through the family, the body of the commonwealth.... It would be irrational to neglect one portion of the citizens and favor another, and therefore the public administration must duly and solicitously provide for the welfare and the comfort of the working classes; otherwise, that law of justice will be violated which ordains that each man shall have his due. To cite the wise words of St. Thomas Aquinas: 'As the part and the whole are in a certain sense identical, so that which belongs to the whole in a sense belongs to the part.' Among the many and grave duties of rulers who would do their best for the people, the first and chief is to act with strict justice - with that justice which is called distributive - toward each and every class alike. (Pope Leo XIII, 1891, Rerum Novarum 33)
}

Since 1891, CST has been centred around this task: using the available sources of knowledge to understand the timeless nature of man and to find an up-to-date balance of his rights and responsibilities to promote both his individual growth and the common good. In 1965, the council Vatican II coined the classic definition of the common good as the 'sum of those conditions of social life which allow social groups and their individual members relatively thorough and ready access to their own fulfillment' (Pope Paul VI, 1965 , Gaudium et Spes 26). The idea behind the common good is that it is meant to benefit all mankind and every single person alike. It is holistic and inclusive. It is mindful of all people and therefore especially of those whose well-being is especially endangered or who are not able to speak for themselves: the poor, the voiceless and future generations. It encompasses adequate economic well-being, health, access to education and information and the ability to express one's thoughts, religious beliefs and ideals, to forge relations and form families and to love and care for relatives, nature and one's cultural heritage. It includes the ability to unfold individual talents and abilities and - in doing this to contribute to the greater common good. Or, as Vatican II looking at the economic and social sphere of a society - described it: 'In the economic and social realms, too, the dignity and complete vocation of the human person and the welfare of society as a whole are to be respected and promoted. For man is the source, the center, and the purpose of all economic and social life' (Pope Paul VI, 1965, Gaudium et Spes 63).

Since the first social encyclical in 1891, CST has tried to balance the right to own private property on the one side and the responsibility for the common good on the other side by pointing out the so-called common destination of goods: ownership is always closely connected to responsibility, and even if an individual or a group might rightly take possession of some assets that, on a more fundamental basis, are meant to serve all, these people are rather responsible curators than unrestricted owners. In the Catholic tradition, this principle is applied, for instance, when discussing the wider responsibility that comes with mining or water rights, with intellectual property or a vast fortune. In his landmark 2015 encyclical Laudato Si', Pope Francis widened the focus and made clear that Planet Earth as a whole is so important to the global common good - and at the same time so vulnerable - that it should be seen and treated as a precious collective good:

Whether believers or not, we are agreed today that the earth is essentially a shared inheritance, whose fruits are meant to benefit everyone. For believers, this becomes a question of fidelity to the Creator, since God created the world for everyone. Hence every ecological approach needs to incorporate a social perspective which takes into account the fundamental rights of the poor and the underprivileged. The principle of the subordination of private property to the universal destination of goods, and thus the right of everyone to their use, is a golden rule of social conduct and 'the first principle of the whole ethical and social order'. ... The natural environment is a collective good, the patrimony of all humanity and the responsibility of everyone. If we make something our own, it is only to administer it for the good of all. (Pope Francis, 2015, Laudato Si' 93 and 95, with a reference to Pope John Paul's 1981 encyclical, Laborem Exercens)

If we really believe in human progress (which is more than just economic or technological progress), any human endeavour that combines such vast resources as the space sector must not only be judged by the financial risks and opportunities of the involved firms, but also by the advancement of the global common good and by the benefit to those who are in most desperate need of these scare resources.

\section{The human rights perspective}

While we took the important principle of the common good as the starting point of our exposition, the most fundamental principle of CST is in fact the principle of personhood: on the one side, this principle helps to articulate the various dimensions of the human existence, resulting in the holistic view of a human being mentioned above; on the other side, it underlines the equal dignity of each and every human being as a person. For CST, this dignity has its deepest basis in the creation of the human person as the image of God, but it is important to note that the insight in this dignity is not only in principle open to other religions and also secular worldviews, but is in fact a widely shared conviction. To a great extent, human rights are based on: (1) this understanding of the equal dignity and holistic personhood of every human being; (2) the insights into the many ways in which dignity and personhood can be disregarded; and (3) the fact that given the sociality of the human person, it can find fulfilment only in a society that strives to protect and enhance personal growth as well as the common good.

Human rights are also often cited as a normative basis for the principle of sustainable development. Given that they indeed are a possible building block towards a theory of sustainable development, human rights are of especial importance given the plurality of worldviews characteristic of our current global culture. They are supported by various ethical theories, are a well-established part of international politics and cooperation and can harmonize with most cultural and religious traditions. Human rights are as universal as the human race; they are not tainted by region, gender or nation, nor ethic, social or religious affiliation. Human 
rights are inviolable, inalienable and indivisible. They complement each other and are therefore not to be played off against each other. In this sense, not only civil and political rights, but also economic, social and cultural rights are to be respected.

Just like the idea of the common good, the idea of human rights is to some extent also based on the observation of our human nature: it is obviously our desire to lead happy and independent lives, and we form groups and states in order to help us fulfil our human potential. Taken together - the universality of these traits and the universality of human dignity - the right to live free and flourishing lives cannot be denied to any human or any human generation, and every human person who denies this right to others can be held responsible. If all men have the same basic right to - according to their own valuation - flourishing lives, we all share the same basic responsibility to grant these rights to everyone: solidarity is inseparable from human rights.

\section{The idea of equal justice: complementing the idea of the common good and the human rights' perspective}

Human rights as codified in the Universal Declaration of Human Rights (United Nations General Assembly, 1948) and international and regional treaties are the result of political negotiations rather than the outflow of one coherent, consistent and comprehensive ethical standpoint. They are presented as a - possibly incomplete - catalogue of rights and are evolving just as our understanding of human nature becomes more holistic and our ethical point of view more inclusive. The claim of universality for human rights, including the rights of future generations, together with the multiplicity of rights in all of their different dimensions (civil, political, economic, social, cultural), as well as tensions between private interests and the claims of the common good, inevitably lead to conflicts, calling for consistent ethical criteria to resolve them. This points to the need for a concept of justice that is able to adjudicate between different and competing claims.

There are many aspects and categories of justice, which in the context of CST, among others, were categorized as, for instance, procedural justice, transactional justice, needs-based justice, equal-opportunity justice and intergenerational justice. These different aspects of justice can be integrated into one unified concept of justice comprising three dimensions or three basic demands of justice. Notwithstanding the great variety of social contexts and different legal and cultural traditions, these three basic demands of justice are necessary preconditions for a free and flourishing life and are relevant always and everywhere:

1. Justice demands that every human person must be able to meet her basic requirements as a human being, which includes everything that is indispensable for her physical and mental well-being. Among these requirements are sufficient food, clean water, clear air, decent housing, physical and mental integrity, sufficient medical care and access to basic education. It is important to consider that some people (e.g., the disabled or the old) might need more or other goods in order to safeguard their well-being.

2. Justice demands an appropriate and supportive assignment of the freedom of action and opportunities to participate, which should help people to satisfy their basic requirements by their own power, to prosper and to develop their individual talents (which in turn serves both the individual and the common good). This implies access to: (1) more than basic education; (2) economic, cultural and political processes and offices;
(3) social services and economic commodities; and (4) supportive networks and positive surrounding conditions that enable solidarity and long-term intact relations.

3. Justice demands that people have an equal voice in defining and altering the institutions, settings and structures that define the conditions that influence the first two aspects of justice mentioned above. This implies the right to fair procedures and to voice one's opinion freely, as well as the right to expect that global standards of good governance are met everywhere from local councils to international bodies.

Each of the three demands of justice stands for itself and cannot be substituted by the others because each one points to a valuable and irreplaceable dimension of human life. At the same time, they are highly interrelated and interdependent. They are to be fulfilled for every human being synchronically and globally for the present generations and diachronically for all future generations, leading naturally to a concept of sustainable development. Given the still widespread lack of fulfilment of the basic demands of justice, there is a need for a process leading to a world where all people are able to freely and responsibly live lives in which all of their demands for justice are met. Given ecological constraints, this process of development has to guarantee as far as possible that these demands are also met for future generations, taking into account the boundaries set by nature, technology, culture and social and economic organization.

\section{Implications of these normative perspectives for the concept of sustainable development}

The aforementioned three normative perspectives may all - individually or together - serve as a sound foundation for the challenging discussion how to define and defend sustainable development - in a small community as well as in states, for the entire Earth or in outer space. They also help to resolve conflicts of goals linked to the concept of sustainable development. This might be illustrated by the so-called three main dimensions of sustainable development - the social, the economic and the ecological aspects - that sometimes are presented as three freestanding pillars, leading to the danger that they are played off against each other. Based on the normative perspectives outlined so far, it becomes clear that these three pillars of sustainable development are quite different in nature, cannot be substituted by each other and always have to be articulated: the social dimension emphasizes the aim of sustainable development; the economic dimension describes a necessary means that should serve this purpose; and the ecological dimension reminds us of our common natural basis that must be preserved. Conceptually, then, sustainable development is not a contradiction in terms, but includes a reminder of the real but historically changing and uncertain natural limits to the economic and social dimensions of development.

CST also provides the conceptual resources to get a clearer view of who is responsible for sustainable development. According to the principle of subsidiarity, the requirements of personal well-being and the common good are always to be fulfilled by the social unit that is able to do so and nearest to those whose good is at stake. If social units or the persons concerned themselves lack the necessary means, they are to be supported in their efforts. Given the global character of many of the challenges of sustainable development, mankind as a whole, all of the nations of the world, the different political units from 
municipalities to regional associations, the many and diverse collective actors of civil society and economic life and every individual person share a joint but differentiated responsibility for the Earth's common good, for human rights and for the basic principles of justice. This corresponds to a bottom-up approach where nobody is left behind and where the extent of responsibility corresponds to capabilities. Subsidiarity encourages and empowers each affected level (and person) to tackle sustainability-related problems immediately instead of shoving the responsibilities, costs and damages elsewhere.

This assignment of responsibilities cannot be imposed from above but - according to the proximate principle of subsidiarity, the basic principle of personhood that includes the respect for human freedom and the third dimension of justice - has to be agreed to on the basis of fair procedures. The annual climate change conferences are good examples of how difficult it is to arrive at such an agreement. But even with those difficulties, the attempt to reach near-universal agreement on questions of climate change set a positive precedent for the question of the economic exploration of space. Here, too, as far as possible, all of the affected - and that includes all of humankind - at least indirectly (and all too often, alas, inadequately) through their governments and social movements taking up the concerns of those not directly represented, should have the chance to have their interests voiced in corresponding negotiations. It cannot be left to the small group of spacefaring nations alone to decide on this question with potentially very far-reaching consequences.

On a much smaller scale, we recently witnessed how these principles can indeed serve as a solid basis for discussion and compromise when we contributed to the work of an interdisciplinary research group on growth and sustainable development (German Bishops' Conference Research Group on International Church Affairs, 2018). This diverse group of economists and ecologists, theologians, philosophers and campaigners had to find common ground first before working on their joint plea for structural reforms and a new appreciation of frugality in public and personal life. The ideals of the global common good, of human rights and of equal justice proved strong enough to overcome all differences of opinion and to motivate fruitful cooperation between the various disciplines.

\section{Catholic social teaching and space ethics}

CST has not explicitly venture into the field of 'space ethics' so far. But if it comes to the basic principles, there is - as the previous sections have shown - no reason to assume that its basic principles of personhood, the common good, solidarity and subsidiarity should not be applicable in space as well. Given the pressing demands of justice and sustainable development on Earth, a first question to answer would be how far the different spacefaring activities are justifiable in themselves. Space projects focusing on the energy and information demands of the global upper and growing middle classes, without any real positive impact on the mounting waste-, energy- or inequality-related problems our planet is facing, are difficult to defend. Especially questionable seem to be projects of space tourism and military uses of space.

One important reason to engage in space projects is the potential need to protect humanity and its existence. Based on CST, the best case could be made for the protection against potentially devastating impacts of asteroids. The danger is real within timeframes that compare with the timeframes considered in environmental discourse, and the protection afforded is - in consonance with the equal dignity of every human being - without distinction.
Projects to save 'humanity' by the means of space travel away from climate change and other human-caused processes of the environmental destruction of our planet seem to be problematic, as they divert means from effective mitigation and can only save a small elite. But there are also hard questions: can or does the expansion of the sun in some billion years justify or even demand huge and long-term efforts in preparation for space travel out of the solar system? Is this possibly a project in the service of the common good, respecting the dignity of every human being? Or should we not focus instead on the pressing needs of the next few hundreds of years?

Another important implication from CST and the ethical principles explained above is that any treaty, regulation or major decision concerning Planet Earth or our terrestrial neighbourhood is likely to affect the rights of all humankind and future generations and has therefore to be discussed and approved by the largest possible number of stakeholders, which makes the United Nations for the time being the most suitable institution for such negotiations. It is also advisable that such a discussion is organized to be as transparent and inclusive as possible, and so that it does not shy away from some of the most basic and pressing questions that are as important in space as they are on Earth. If the text of a proposed agreement remains vague or elusive on these basic questions, it is not likely to serve the interests of the people in whose name it is signed:

1. Do we understand Earth and its surrounding space (including planets and asteroids) as a collective good, serving the common good of recent and future generations, or as a firstcome-first-served shopping market? In 1967, the Outer Space Treaty stated that the use of outer space is only allowed 'for the benefit and in the interests of all countries' (Art. I) - a resolution that should be upheld and made a guiding principle for future negotiations (United Nations, 1967). This historic document (whose wording future generations might want to change from 'all countries' to 'all people' or 'all creatures') was drafted after long international debates and was based on a clear ethical foundation, whereas recent suggestions to 'encourage bilateral and multilateral agreements between the concerned countries' (Losch, 2019, citing a proposal by the government of Luxembourg, which was later discarded) would set a questionable precedent. The fact that some governments are even likening the legal aspects of extracting minerals in space 'to deep-see fishing in international waters' (Losch, 2019) should be a dire warning considering our oceans' poor condition.

2. Who should profit and who pays the price? If Planet Earth and space are indeed collective goods, this leads to questions of how potential profits could be more equally distributed between all people, especially those in need (as proposed by the Space2030 framework; United Nations, 2019) and of who will be held accountable (and by whom) for a just balance of the investments, external costs and dividends of space activities. In space as well as on Earth, mankind cannot afford any additional activities that are long-term profitable only by passing on the external costs to other parties. Human history teaches us that collective goods can only be sustained if there are just and transparent rules (Grüne et al., 2016), such as 'those who use it, clean it', a rule that might also be applicable when dealing with the growing problem of space debris.

3. What is our general attitude towards life and any rights attributed to it? If we should ever encounter extra-terrestrial life, it would be too late for this debate. As on Earth, there will always 
be conflicts of interest (even if not intended), and we would be forced to differentiate: we would judge different lifeforms most likely by their complexity, certainly by their potential use or threat, maybe by region or by their position in their natural habitat. But there can be no doubt: if we ever should encounter other lifeforms that could be described as real 'persons', they would undeniably have personal and collective rights. If space travel should become an option or even a necessity one day, we will also face the difficult question of which species to take along and how to safeguard their rights and interests.

Coming back to the SDGs we mentioned in the Introduction and that for now rally the international efforts for sustainable development, would it be helpful to introduce an additional 18th SDG (Galli \& Losch, 2019) in order to make sure that these important questions are adequately taken into account when discussing human activities transcending Planet Earth? Based on our understanding of CST, we are convinced that we does not need a new set of ethical principles to guarantee justice or sustainability in space. Nevertheless, it is vital for truly sustainable development that, especially in the light of new challenges, there is a continuing, forward-looking discussion of these values, which remind us that our world (including space) is a shared heritage that can only be preserved when all SDGs are seen in their unity: they cannot be broken up and played off against each other. The main contribution of CST to the idea of sustainable development is not so much about what exactly should be done, but mainly how and why as many people as possible - potentially all, without exclusion - should participate, contribute and share in the benefits of development. Thus, a potential 18th SDG, as recommend by a growing number of scientist (Galli \& Losch, 2019), should not only lay out new rules for activities transcending Earth, but also serve as a reminder of the basic human principles that respect and foster life (and all rights connected to it), encourage subsidiarity and strive to attain the best possible amount of human freedom and solidarity. Its function would be to summarize the central principles of true sustainable development and to underline their relevance for all newly arising challenges, such as the need for sustainable and fair use of outer space. Then, the aim of the SDGs to promote 'peace and prosperity for people and the planet' will guide all of our human activities - in space as on Earth. The discussion of 'space ethics' - as new and challenging as it might seem to traditional CST - is in fact a great chance to reflect on our ethical standards here on Earth and on how we can best live up to them wherever we are.

\section{Acknowledgements. None.}

Author contributions. The authors Johannes Wallacher, Stefan Einsiedel and Andreas Gösele wrote this article together.

Financial support. This research received no specific grant from any funding agency, commercial or not-for-profit sectors.

Conflicts of interest. None.

Ethical standards. This research and article complies with Global Sustainability's publishing ethics guidelines.

\section{References}

Galli, A. \& Losch, A. (2019). Beyond planetary protection: what is planetary sustainability and what are its implications for space research? Life Sciences in Space Research. In press. https://doi.org/10.1016/j.lssr.2019.02.005.

German Bishops' Conference Research Group on International Church Affairs (2018). Raus aus der Wachstumsgesellschaft? Eine sozialethische Analyse und Bewertung von Postwachstumsstrategien. Retrieved from https://www.dbkshop.de/media/files_public/okvnwjpxcib/DBK_1521.pdf.

Grüne, N., Hübner, J. \& Siegl, G. (2016). Ländliche Gemeingüter. Kollektive Ressourcennutzung in der europäischen Agrarwirtschaft/Rural Commons. Collective Use of Resources in the European Agrarian Economy. Jahrbuch der Geschichte des ländlichen Raums 2015. Studienverlag.

Habermas, J. (2010). An awareness of what is missing. In M. Reder \& J. Schmidt (eds.), An Awareness of What Is Missing: Faith and Reason in a Post-Secular Age (pp. 15-23). Polity Press.

Hollenbach, D. (2002). The Common Good and Christian Ethics. Cambridge University Press.

Losch, A. (2019). The need of an ethics of planetary sustainability. International Journal of Astrobiology, 18, 259-266.

Pope Francis (2015). Encyclical Letter Laudato Si'. Retrieved from http:// w2.vatican.va/content/francesco/en/encyclicals/documents/papa-francesco_ 20150524_enciclica-laudato-si.html.

Pope Leo XIII (1891). Encyclical letter Rerum Novarum. Retrieved from http://w2.vatican.va/content/leo-xiii/en/encyclicals/documents/hf_l-xiii_enc_ 15051891_rerum-novarum.html.

Pope Paul VI (1965). Gaudium et Spes. Pastoral Constitution on the Church in the Modern World. Retrieved from http://www.vatican.va/archive/hist councils/ii_vatican_council/documents/vat-ii_const_19651207_gaudium-etspes_en.html.

Rawls, J. (1971). A Theory of Justice. Harvard University Press.

Redclift, M. (2005). Sustainable development (1987-2005): an oxymoron comes of age. Sustainable Development, 13, 212-227.

Reder, M. \& Müller, J. (2012). Cultures and religions. In: O. Edenhofer, J. Wallacher, H. Lotze-Campen, M. Reder, B. Knopf \& J. Müller (eds.), Climate Change, Justice and Sustainability: Linking Climate and Development Policy (pp. 111-118). Springer.

Robinson, J. (2004). Squaring the circle? Some thoughts on the idea of sustainable development. Ecological Economics, 48, 369-384.

Scheid, D. (2016). The Cosmic Common Good. Religious Grounds for Ecological Ethics. Oxford University Press.

Stiglitz, J., Sen, A. \& Fitoussi, J.-P. (2009). Report of the Commission on the Measurement of Economic Performance and Social Progress. Retrieved from https://ec.europa.eu/eurostat/documents/118025/118123/Fitoussi+Commission +report.

Tatay, J. \& Devitt, C. (2017). Sustainability and interreligious dialogue. Islamochristina, 43, 123-139.

United Nations (1967). Treaty on Principles Governing the Activities of States in the Exploration and Use of Outer Space, including the Moon and Other Celestial Bodies (a.k.a. 'Outer Space Treaty'). Retrieved from http://www. unoosa.org/pdf/gares/ARES_21_2222E.pdf.

United Nations (2019). Zero draft of the 'Space2030' Agenda and implementation plan. Retrieved from http://www.unoosa.org/res/oosadoc/data/documents/2019/aac_1051/aac_1051_317_0_html/V1903343.pdf.

United Nations General Assembly (1948). Universal Declaration of Human Rights. Retrieved from https://www.un.org/en/ga/search/view_doc.asp? symbol=A/RES/217(III).

United Nations General Assembly (2015). Transforming our world: the 2030 Agenda for Sustainable Development, 21 October 2015 (a.k.a. 'Sustainable Development Goals'), A/RES/70/1. Retrieved from https://www.refworld. org/docid/57b6e3e44.html.

Welty, E. (1951). Sozialkatechismus. Herder. 